\title{
The Complexity of Public Relations Work
}

\author{
PR Managers in the Public and Private Sector \\ in Sweden
}

\author{
Bengt Johansson \& Larsåke Larsson
}

\begin{abstract}
Research on the PR-function is extensive, especially in the US and the UK. The managertechnician dichotomy is well known, but has been challenged by recent research where more nuanced perspectives on PR-managerial roles are displayed. In relation to this complexity of PR-managerial roles the article investigates the function and role Swedish public relations managers perform and play in their organizations. The Swedish case, with its high proportion of PR practitioners employed by public authorities, was used to further explore the complexity of PR work. The empirical data was a survey distributed to a random sample of members of the Swedish Public Relations Association, with a managerial or head/ director position, representing all industry/societal sectors. 261 persons completed the survey, giving a response rate of 30 percent. The study confirmed previous research of a more complex picture of the PR-managerial level. One important conclusion was therefore that the simple dichotomy between managers and technicians cannot be used to understand managerial level positions in the public relations context. This complexity was even further emphasized when comparing PR-mangers in the private and the public sector. One challenge pointed out for future research was to develop analyses of PR managerial roles in different types of organizations.
\end{abstract}

Kewords: PR, PR managers roles, practitioners roles, information/communication managers, $\mathrm{PR}$ role research

\section{Introduction}

Working with public relations may include performing a wide range of tasks, from strategic contributions in order to analyze and advise CEOs, to overseeing visual design of information materials. PR practitioners, especially those occupying managerial positions, must be considered to have a wider remit than many other professional groups in organizations.

In research on the PR function, practitioner roles have been intensively studied, especially in the US and UK. The tension between different roles performed by these practitioners has often been described in the framework advanced by Broom and Smith (1979) in the form of their four-role typology, which has been reconfigured in several studies, among them by Moss et al. (2005) into a five-role typology. In Sweden, and to the same degree in the other Nordic countries, there are rather few previous studies of 
PR practitioners' roles. The first question for the present study is thereby: What function and role do Swedish public relations managers perform and play in their organizations?

Historically, the PR professional corps is a rather recent member group in Swedish organizations. Swedish PR practitioners, like their international colleagues described in literature, may be expected to play a rather varied role, not only performing communication tasks but also a broad range of other duties, for example duties of a service, advisory and crisis management character. The Swedish and Nordic organizational and societal context, however, differs in at least one important respect from many other countries, which might be important with regard to the PR practitioner's role. In the Nordic countries, the public sector is more extensive and almost half of the total group of PR practitioners is employed by public authorities. Working within this sector can be assumed to entail a partly different set of roles, for instance communicating with the general public. Moreover, this work is guided by the principle of public access to official records. The second question for this study is therefore: How do managerial roles differ between PR practitioners working in the private and those working in the public sector?

\section{Previous Research - PR Practitioner Roles}

Organizational roles are abstractions or conceptual tools for summarizing the salient features of organizational members' activities and behavior (Dozier \& Broom 2006). Katz and Kahn defined an organizational role as "recurring actions of an individual, appropriately interrelated with the repetitive activities of others so as to yield a predictable outcome" (Katz \& Kahn 1978:189).

Public relations practitioner roles have been subjected to extensive research, especially in the US, but also in the UK. Roles research has been focused on how roles should be described and characterized as well as on exploring other related dimensions, among them the question of gender, power and position in the organizations' leading decision-making bodies (see e.g., Toth et al. 1998). The principal focus, however, has been on exploring the key typologies or what role types there are to be found among PR practitioners.

Two forms of typologies are predominant in the role research. The first is the Broom and Smith (1979) typology, composed of four types of practitioners (expert prescriber, communication facilitator, problem solver and communication technician). The other is Dozier's subsequent reconfiguration into a two-type model, the manager-technician dichotomy (Dozier 1984; Broom \& Dozier 1986). Broom and Dozier's typology has been widely used in a number of role studies (Dozier \& Broom 2006), in its original form or in elaborated forms.

A managerial perspective has come to be one line of thought in the role domain, especially in the US (see Dozier \& Broom 2006). Within this perspective, being a member of the dominant coalition in organizations has been a key concept and norm for public relations managers (Doizier et al. 1995; J. Grunig 1992; L. Grunig et al. 2002). In connection with this, Wright (1995) suggested the existence of a third role, the communication executive, as an addition to the manager-technician typology.

The managerial perspective has been challenged in several ways, with ideological as well as methodological and empirical criticism. DeSanto and Moss (2004) argue that the notion of public relations managers operating as part of the dominant coalition in organizations has been shown to be more of a normative aspiration than a reflection of the 
reality found in most organizations (see also Moss, Warnaby \& Newman 2000). Berger (2005) suggests that a single dominant coalition within organizations is too simplified and a 'myth'. Rather, he argues that a multitude of decision-making coalitions may exist with changing memberships and power. Reber and Berger found that relatively few of their respondents argued that having a seat at the decision-making table was the primary indicator of having genuine influence. Public relations practitioners are most influential when organizations face crises, but lack influence in strategic decision-making (Reber \& Berger 2006).

Critics of the managerial-technical role line of though also suggest that this model oversimplifies PR practitioners' work and role enactment, which needs to be understood in a much broader sense as it is a more complex phenomenon involving a wide range of communication and relational activities (Moss \& Green 2001; see also Leichty \& Springston 1996). A further distinction is made by Moss, Newman and DeSanto (2005), who have argued for the need to distinguish between managerial tasks or responsibilities and managerial behaviors. They reason that "Public relations roles research has offered a relatively simplistic one-dimensional view of management, focusing largely on the reported 'tasks' performed by public relations managers, and largely ignoring the 'how' and 'why' dimensions of management" (Moss, Newman \& DeSanto 2005: 877).

Moss et al. worked with a partly different measurement instrument than is typically used in role studies and identified five dimensions or core areas of practitioner work where these actors are a) monitor and evaluator, b) key policy and strategic advisor, c) trouble shooter/problem solver, d) issues management expert and lastly e) communication technician. In sum they thus found four managerial responsibilities and one technical role (Moss, Newman \& DeSanto 2005).

Another line of criticism of the managerial perspective, expressed not least by some European researchers, claims that public relations is better viewed as a socially oriented concept of organizations rather than as a professional management function per se (Ihlen \& van Ruler 2009). Drawing on the findings of the Delphi study, van Ruler et al. (2001) identified four characteristics of European public relations, namely the reflective, managerial, operational and educational features. The reflective dimension refers to observing and assessing the organization in connection with its mission and strategies and the educational dimension refers to increasing communicative competence within the organization (van Ruler \& Vercic 2004).

A study investigating PR practitioners in 30 European countries was carried out by a Swiss research group, using cluster analysis on the same 24-item question battery on role activities once developed by Broom and Smith. This study also resulted in a typology with five roles. The role cluster consists of lobbying (with external constituencies), advising and analysis, market positioning, internal support and external service. The labels applied to the actors performing the roles within these clusters were: negotiators, policy advisers, brand officers, internal communicators and press agents (Beurer-Züllig, Fieseler \& Mecel 2009).

An even larger European project, with almost 2000 participants in 46 countries, and focusing on their business supporting status, found four professional PR managerial roles: the strategic facilitator, the business adviser, the isolated expert and the operational supporter. Almost 60 percent belong to the strategic facilitating group, while roughly one of four was an operational supporter and one in ten an isolated expert. The business 
advisers were rather few in number. A comparison between the European regions shows that PR professionals in the northern countries are slightly more likely to be strategic facilitators than those in the other regions, while those in Western Europe are operational supporters to a higher degree and those in the southern countries are more likely to be isolated experts than those in the other regions (Zerfass et al. 2010).

In most studies, one role in particular is the same: the strategic role. This role also scores high in several recent studies in South Africa. Steyn (2009) identifies the strategist as the first of three roles, the two other being the managerial and the technician roles. The strategic PR practitioner is a planner as well as an issues manager and stakeholder expert, but also a reflective agent, therefore Steyn compares the strategist type with the reflective function in the European Delphi-based study. In another study in the same country, Tindall and Holtzhausen (2011) found four roles - the strategist, media specialist, liaison and cultural interpreter - where the liaison is the relationship builder and the cultural interpreter works in connection with the differentiated cultural and ethnic landscape of South Africa. The emphasis on the strategic function in public relations also appears in recent studies in the US conducted by Werder and Holtzhausen (2009 and 2011).

Based on a study of the competencies of leading English communication executives, Gregory (2008) emphasizes the relational dimension of PR practitioners' roles and tasks, a dimension that can be viewed as having been underrated in most traditional studies. In line with her findings, Choi and Choi (2009) stressed the relational dimension in a PR leadership behavior study, identifying important roles such as networking, coordinating and representing together with being an agent for change.

A Swedish (interview) study of communication executives shows that PR managers have a clear strategic and managerial role within their organizations, and also work with internal and external communication. The executive role involves three different types of performance: the organizational leader, the communication leader, and the communication manager. Executives perceived high external legitimacy, whereas internal legitimacy varied across organizations. The formal status varies, from those who are full members of the highest decision-making group to those who are outside this group; thus such status is individual and has to be negotiated. One problem and risk with PR managers' ambition to increase their status and come closer to the top level is that they lose their relations and contacts with the rank and file (Johansson \& Ottestig 2011).

To summarize the findings of previous research, we find that even if there are differences between identified roles, similarities are more prevalent. The strategist function is emphasized in most studies, and depending on the scope and focus of the study, other functions and roles are also emphasized, where relational dimensions and crisis management are frequent. It is also clear that the simple managerial-technician distinction has been questioned and that different types of managerial and expert roles are found. However, the same differentiation of the more technical, day-to-day roles of PR work has not been elucidated in a similar way.

\section{The Swedish Public Relation Industry}

Public relations, in the sense of functions set up in organizations for executing PR and information, started in Sweden during World War II, much later than in the US, UK and Germany. The very first PR practitioners were appointed to the Swedish State Infor- 
mation Bureau and had the double purpose of informing and propagating - to inform (and steer) the media in war affairs and to create propaganda for the public to promote both awareness of hostile persons and activities as well as for thriftiness in industry and housekeeping (because Sweden was neutral in the war, it was isolated and received no material imports). After the war several public authorities, together with lager companies, established PR departments. In Sweden, the PR industry started in the state/ public sector, not in business as in many other countries. A few PR agencies started in the 1950s (Larsson 2005).

By the 1960s larger industrial companies had generally established PR functions, not least as a response to the advent of environmental movements attacking them. New laws regulating internal information to employees contributed to this development. By the 1970s, the public sector in Sweden expanded substantially; state, regional and local authorities and institutions set up information departments and employed PR practitioners, usually those with university degree. The PR industry subsequently remained stagnant in terms of number of members, and even decreased at the end of the 1980s due to rationalizations, in both the private and public sector. Nevertheless, from the middle of the 1990s, the PR-industry increased again rapidly just before the millennium shift. Companies and authorities also engaged PR experts in subdivisions and subsidiaries. PR and communication consultancies also increased profoundly during this period (Larsson 2005).

The present development and growth of the Swedish PR industry parallels, and is a result of the fundamental shift in the political system during the past two decades. Once a state with an evident corporative political system where different interest groups were represented in government bodies, Sweden has changed to a more liberal marketoriented society where interests compete for political power by performing in different ways. Whereas these groups (businesses, unions and other organizations) previously participated as members in state committees and expressed their opinions in a solid remittance system, they now have to seek influence through lobbying, the mass media, opinion building and other means. At present, the previous situation of nearly complete institutional representation is increasingly characterized by the participation of noninstitutional actors, among them PR actors (Gilljam \& Hermansson 2003; Larsson 2006).

Today the PR industry in Sweden is estimated to comprise some 10,000-15,000 professional practitioners. The share of consultants within the PR industry is comparatively low; one out of five belongs to consultancy firms, while the rest are employed as staff in companies, public authorities and organizations. 75 percent of the total of the professional body are women and almost one in two PR managers is a woman. Another feature of the Swedish PR landscape is the relatively large share of practitioners in the public sector, owing to the size of this sector in the country (Flodin 2004; Larsson 2005). Almost half of the total number of PR practitioners are estimated to work in public sector bodies; of the total membership of 5300 people 2010 (cf. 6100 members 2013) in the Swedish Association of Communication Professionals, 33 percent work in the private sector (companies) while 40 percent are employed in the public sector (government and state/local/regional authorities and companies). leaving 27 percent working in interest organizations and consulting firms (SACP, 2010).

This overview shows that the development of the PR industry in Sweden traditionally relies heavily on demands from the public sector. In most other advanced democracies (outside the Nordic region), the development of the PR industry has been different. In 
these countries the private sector, including the needs of privately owned companies and interest groups, has been more important for the growth of the PR industry (see, e.g., Broom \& Sha 2013).

\section{Methodology}

The survey instrument used in the present study is the same as developed by Moss, Newman and DeSanto (2005). Survey items were constructed on a series of sevenpoint semantic differential scales. The instrument was a self-administered postal survey with 47 items covering eight operational dimensions of managerial work: Counseling/ advisory responsibility, issues management, policy and strategy, trouble shooting and problem solving, administration, monitoring and evaluation, negotiation, and technical responsibilities, completed with classification and demographic sections. These operational dimensions drew on analyses of PR practitioners' narratives in earlier qualitative studies, focusing on their daily tasks and activities (DeSanto \& Moss 2004).

The survey population in the present study was randomly selected from a list of all members of the Swedish Public Relations Association, with a managerial or head/director position, representing all industry/societal sectors. In the first round, 900 persons were selected, whereupon consultants were eliminated. The population then comprised 886 persons who received the survey by post. Eleven of these were not to be found at the address or related that they were no longer in the occupation, which left a net sample of 875 persons. Of these, 261 persons completed the survey (the original English version), giving a response rate of 30 percent. Table 1 illustrates the distribution of respondents within sectors.

Table 1. PR Practitioners Distributed within Sectors

\begin{tabular}{lcc} 
Type & Frequencies & Percent \\
\hline Private companies & 109 & 41.6 \\
State/public companies & 16 & 6.1 \\
Organizations & 22 & 8.4 \\
Education & 6 & 2.3 \\
Government/authorities & 91 & 34.7 \\
Other & 17 & 6.5 \\
Missing & 1 & 0.4 \\
Total & 262 & 100 \\
\hline
\end{tabular}

The table shows that 42 percent of the respondents are working in private companies or in the private sector. In comparison, 37 percent belong to the public sector, comprising those working in central and local governments, authorities and education bodies. The last group (21 percent) consists of those working in (interest) organizations, state/public companies and a category defined as "other" (employed in, e.g., Swedish broadcast radio/television (SR/SVT) and churches). Within the private sector, almost half of the respondent group work in manufacturing companies, one fourth in trade and transport companies, one fifth in the finance sector and the rest in companies dealing with private service (e.g., consulting, energy and tourism). In terms of gender, 67 percent of those answering the questionnaire are female and 33 percent male. 
In a response analysis, the question is whether the responding and non-responding groups differ in certain respects. Regarding gender, the division between men and women in the respondent group is quite similar to the gender division in the Swedish PR professional group as a whole. Regarding e.g., position and place of work, the division into sectors/trades is the same as that seen in general measurements performed by the Swedish Association of Communication Professionals (SACP 2010). The low response rate corresponds to results in a number of similar role studies; for instance, the response rate in Moss et al. (2005), using the same instrument as used in the present study, was 25 percent.

\section{Findings}

Dimension analysis is a tool commonly used in social sciences to discover latent dimensions of attitudes, values, role perceptions and lifestyles etc. (Bartholomew et al. 1979). Factor analysis is the type of dimension analysis technique chosen in the present study, the purpose of which is to explore the dimensions of responsibility and tasks of the respondents in their respective organizations. Exploratory factor analysis tries to uncover new dimensions and constructs in a given dataset, where data in the social sciences are typically obtained through surveys. The idea is to summarize the information contained in a large number of responses to different questions by deriving a small number of latent factors/dimensions. These factors/dimensions are not visible in the responses to each question, but are a result of the relationships between interrelated variables (Galbraith et al 2002).

Principal Component Analysis (PCA) factor analysis was used to summarize and explore dimensions of the PR practitioner role; it revealed the presence of ten factors, each achieving eigenvalues greater than one. Together these factors explained 66 percent of the total variance. To simplify and reduce the dimensions a number of tests were used: the computation of total variance explained and a Scree test (where the slope of the line changes). After conducting a varimax rotation of the dataset, judgments of the strength of the factor loadings were made. Loadings below .30 were considered poor and those items were left out of the dimension; .40 was estimated as significant and loadings higher than .60 were considered as strong (cf. Moss, Newman \& DeSanto 2005)

\section{PR Mangers at Work}

The PCA performed on Swedish PR managers indicates a five dimensional solution, where all five factors show high internal reliability. The results of the analysis are displayed in Table 2:

The first and most pronounced dimension (explaining 26 percent of the variance in the factor solution) is labeled monitor and evaluator. It consists of 12 items with high internal reliability and consistency (Cronbach's alpha .85). The dimension captures central aspects of management responsibility, where managers are supposed to organize, supervise and control the PR function of the organization, both internally and externally. It largely concerns strategic work, formulating strategies for the PR function in relation to management and evaluating the function of PR in the organization.

The second dimension captures the role of being an issues management expert. The role includes managing programs to address identified issues and dealing with any un- 
Table 2. Dimensions of Public Relations Practitioner's Role

Fact Fact Fact Fact Fact

$\begin{array}{lllll}1 & 2 & 3 & 4 & 5\end{array}$

\section{Monitor and evaluator}

Monitoring the performance of the PR-function $\quad .75$

Commissioning external agencies to evaluate communication strategies $\quad .68$

Negotiating about resources \& workloads for the PR department/function $\quad .68$

Ensure PR/communication function operates within the agreed budgets $\quad .67$

Setting targets for the public relations function $\quad 65$

Negotiate with the senior management about goals for the PR-function $\quad .56$

Prepare regular reports about the communications function $\quad .55$

Determine appropriate targets/benchmarks for the PR-function .53

Represent the PR-function at meetings $\quad .51$

Formulating PR-strategy in collaboration with top management $\quad .46$

Managing staff $\quad .44$

Commission external agencies to carry out the technical production of work $\quad .43$

\section{Issues Management Expert}

Collect and analyze intelligence

$\begin{array}{ll}\text { Recommend how the organization should respond to the threats } & .78\end{array}$

$\begin{array}{ll}\text { Monitor external trends that might affect the organization } & .75\end{array}$

$\begin{array}{ll}\text { Managing programs to address identified issues } & .63\end{array}$

$\begin{array}{ll}\text { Dealing with unexpected events that threatens the organization } & .54\end{array}$

\section{Key Policy and Strategy Advisor}

Contribute to top management policy making meetings $\quad .68$

Work with the CEO ensure the PR-implication of any decision is understood $\quad .65$

Implementing the organization's communication strategies $\quad .59$

Advise CEO about how strategic decisions will be viewed by the media $\quad .58$

Advise top management business/communication issues \& challanges $\quad .53$

Oversee the visual/design materials for my organization $\quad .52$

Advise management largely about how best to present its politics $\quad .49$

In corporate decisions at board level $\quad .47$

Engage in contacts with the media $\quad .34$

Ensuring that the communications reporting systems are working $\quad .32$

\section{External Communication Expert}

$\begin{array}{ll}\text { Manage issues arising from conflicts with external stakeholder groups } & .80\end{array}$

Advise top management on a variety of important stakeholder issues $\quad .68$

$\begin{array}{ll}\text { Liaising and negotiating with external stakeholder groups } & .64\end{array}$

Planning PR strategies for key internal/external stakeholders $\quad .60$

Expert dealing with major/minor crises affecting my organization $\quad .54$

$\begin{array}{ll}\text { Draft or help draft the Chairman's speeches } & .39\end{array}$

\section{Communication Manager}

Dealing with routine, day-to-day organizational administration $\quad .63$

Handle technical aspects of producing communication/public relations work 61

Day to day demands for PR-support from others within the organization 58

Resolve problems caused by others in the organization $\quad .56$

"Fire fighting" a range of internal/external challenges $\quad .50$

\begin{tabular}{ll} 
Exchanging information \& negotiating over control of information & 48 \\
\hline
\end{tabular}

Note: Extraction Method: Principal Component Analysis. Rotation Method: Varimax with Kaiser Normalization. 
expected internal/external events threatening the organization. Other tasks belonging to issues management include analyzing intelligence, recommending how to respond to threats from major trends/issues and monitoring external trends. Analyzing internal reliability (Cronbach's alpha .81) reveals the unidimensionality of the factor.

The third dimension discerned is the key policy and strategy advisor (Cronbach's alpha .81). This dimension captures the role in which managers work closely with top management in the organization, ensuring that the PR and communications implications of decisions are understood, advising senior management on how the media will react to different decisions, and advising management on how politics should be presented. This function implies a position in the top management team of the organization. It also includes more actual PR work in the organization, such as overseeing visual/design material and media contact as well as being a spokesman for the organization.

A fourth dimension can be named stakeholder expert (Cronbach's alpha .80). Advising top management of stakeholder issues, managing stakeholder issues, and negotiating and planning activities in relation to external stakeholders all belong to this role. Although the task of drafting or helping to draft chairman's speeches belongs to this dimension in the factor solution, it is a weak tie. When testing reliability, the index would be more coherent if the item were deleted.

The last dimension is the communication manager; it receives a lower internal consistency score in relation to other factors in the dataset (Cronbach's alpha .68). The role includes different aspects of PR practice, day-to-day routine activities such as supplying other departments of the organization with PR support, answering e-mail, and solving immediate communication problems in the organization. The data indicate that Swedish PR managers are less involved only with technical duties. Therefore the factor contains both tasks and responsibilities related to routine hands-on activities as well as extraordinary situations of conflict that could threaten the organization.

\section{Managerial Roles in the Private and Public Sector}

The Swedish PR profession shows two different trajectories, one related to tasks in the public sector and the other more focused on meeting the needs of private enterprises (Larsson 2005). The second main question addressed in the present article was to determine whether similar or different dimensions of managerial roles of the PR function can be found in the private and public sector. Will the same dimensions of roles found on the general level discern when managers in the private and public sector are analyzed separately? The results of analyses of PR managers' roles in the public and private sector are shown in Table 3 and 4:

Executing a PSA split on managers in the private and public sector indicates that the composition of managerial roles differs between these sectors. We also find some divergences in relation to the general picture of PR practitioners' role as shown in Table 2.

The first observation is the difference between the factors explaining the largest proportion of the variance. The roles as monitor and evaluator and key advisor and policy strategist cannot be separated in the private sector; the dimension is clearly the most significant (26\% variance explained). This indicates that strategic work - such as monitoring and being a policy strategist - is not separated in different managerial roles in the private sector. In other words, it seems as though the strategic PR function is more 
Table 3. Managerial Roles among Swedish PR-managers Working in Private Sector

\begin{tabular}{cccccc} 
Fact & Fact & Fact & Fact & Fact \\
& 1 & 2 & 3 & 4 & 5 \\
\hline
\end{tabular}

\section{Key Policy and Strategy Advisor \& Monitor and evaluator}

Monitoring the performance of the PR-function $\quad .79$

Work with the CEO ensure the PR-implication of any decision is understood $\quad .76$

Determine appropriate targets/benchmarks for the PR-function $\quad .74$

Ensure PR/communication function operates within the agreed budgets $\quad .71$

Prepare regular reports about the communications function $\quad .70$

Implementing the organization's communication strategies $\quad .68$

Setting targets for the public relations function $\quad 68$

Advise top management business/communication issues \& challenges $\quad .60$

Contribute to top management policy making meetings $\quad .60$

Commissioning external agencies to evaluate communication strategies $\quad .59$

Negotiate with the senior management about goals for the PR-function $\quad .58$

Represent the PR-function at meetings $\quad .55$

Formulating PR-strategy in collaboration with top management $\quad .50$

\section{Issues Management Expert}

$\begin{array}{ll}\text { Monitor external trends that might affect the organization } & .79\end{array}$

$\begin{array}{ll}\text { Recommend how the organization should respond to the threats } & .78\end{array}$

$\begin{array}{ll}\text { Collect and analyze intelligence } & .78\end{array}$

Advise management largely about how best to present its politics $\quad .62$

Advise CEO about how strategic decisions will be viewed by the media $\quad .62$

Managing programs to address identified issues $\quad .53$

Engage in contacts with the media $\quad .49$

\section{External Communication Expert}

Manage issues arising from conflicts with external stakeholder groups $\quad .81$

Liaising and negotiating with external stakeholder groups $\quad .72$

Planning PR strategies for key internal/external stakeholders $\quad .70$

Advise top management on a variety of important stakeholder issues $\quad .61$

Expert dealing with major/minor crises affecting my organization $\quad .57$

Managing staff $\quad .50$

Draft or help draft the Chairman's speeches $\quad .44$

\section{Trouble-shooter, Problem-solver}

Resolve problems caused by others in the organization $\quad .75$

Day to day demands for PR-support from others within the organization $\quad .68$

"Fire fighting" a range of internal/external challenges $\quad .60$

Negotiating about resources \& workloads for the PR department/function $\quad .54$

Dealing with routine, day-to-day organizational administration $\quad .49$

Dealing with unexpected events that threatens the organization $\quad .47$

Deal with e-mail and other correspondence $\quad .42$

\section{Communication Technician}

Handle technical aspects of producing communication/public relations work 68

$\begin{array}{ll}\text { Oversee the visual/design materials for my organization } & .61\end{array}$

$\begin{array}{ll}\text { Ensuring that the communications reporting systems are working } & .50\end{array}$

Exchanging information \& negotiating over control of information $\quad .41$

$\begin{array}{ll}\text { In corporate decisions at board level } & .37\end{array}$

Note: Extraction Method: Principal Component Analysis. Rotation Method: Varimax with Kaiser Normalization. 
Table 4. Managerial Roles among Swedish PR-managers Working in Public Sector

\begin{tabular}{cccccc} 
& Fact & Fact & Fact & Fact & Fact \\
& 1 & 2 & 3 & 4 & 5 \\
\hline
\end{tabular}

\section{Issues Management Expert/Trouble shooter}

Collect and analyze intelligence $\quad .80$

Recommend how the organization should respond to the threats $\quad .76$

Managing programs to address identified issues $\quad .69$

Monitor external trends that might affect the organization 65

Dealing with unexpected events that threatens the organization 62

"Fire fighting" a range of internal/external challenges $\quad .60$

In corporate decisions at board level .52

Expert dealing with major/minor crises affecting my organization $\quad .50$

Draft or help draft the Chairman's speeches $\quad .44$

\section{Key Policy and Strategy Advisor}

$\begin{array}{ll}\text { Advise top management on a variety of important stakeholder issues } & .77\end{array}$

Advise top management business/communication issues \& challenges $\quad .74$

$\begin{array}{ll}\text { Contribute to top management policy making meetings } & .74\end{array}$

Manage issues arising from conflicts with external stakeholder groups $\quad .65$

Advise CEO about how strategic decisions will be viewed by the media $\quad .60$

Advise management largely about how best to present its politics $\quad .60$

Planning PR strategies for key internal/external stakeholders $\quad .48$

Work with the CEO ensure the PR-implication of any decision is understood $\quad .48$

Implementing the organization's communication strategies $\quad .45$

\section{Communication Manager}

Dealing with routine, day-to-day organizational administration $\quad .70$

Day to day demands for PR-support from others within the organization $\quad .67$

Resolve problems caused by others in the organization $\quad .65$

Negotiating about resources \& workloads for the PR department/function $\quad .59$

Negotiate with the senior management about goals for the PR-function $\quad .55$

Managing staff $\quad .53$

Handle technical aspects of producing communication/public relations work .51

Ensuring that the communications reporting systems are working $\quad .49$

Exchanging information \& negotiating over control of information $\quad .48$

Prepare regular reports about the communications function $\quad .42$

Liaising and negotiating with external stakeholder groups $\quad .37$

\section{Monitor and Evaluator}

Monitoring the performance of the PR-function $\quad .66$

$\begin{array}{ll}\text { Setting targets for the public relations function } & .64\end{array}$

Commissioning external agencies to evaluate communication strategies $\quad .61$

Determine appropriate targets/benchmarks for the PR-function $\quad .56$

Commission external agencies to carry out the technical production of work $\quad .52$

Formulating PR-strategy in collaboration with top management $\quad .52$

$\begin{array}{ll}\text { Represent the PR-function at meetings } & .50\end{array}$

\section{Communication Technician}

Engage in contacts with the media $\quad .52$

Oversee the visual/design materials for my organization $\quad .46$

Note: Extraction Method: Principal Component Analysis. Rotation Method: Varimax with Kaiser Normalization. 
or less in the hands of one person in private companies. The most significant dimension found among PR practitioners in the public sector is instead the role as issues management expert (21\%), dealing with, e.g., intelligence and trend analysis. This might also indicate that monitoring and work analyses have a weaker position for PR mangers in the public sector compared with its private counterpart.

Another general disparity, as seen in Table 3 and 4, is that the dimension as external communication expert and trouble shooter/problem solver can only be found among employees in the private sector. On the other hand, the communication manager dimension is only visible among practitioners in the public sector. Looking in more detail at this dimension, we find some of the external communication tasks identified as a dimension of its own among practitioners in the private sector. External communication also seems to be a part of the work for managers in the public sector, among those who prefer to work with monitoring and evaluating.

When separating the analysis into two sectors, another dimension is detected, concerning the communications technician who works with overseeing visual design, handling technical aspects of PR work and ensuring that the communications reporting systems are working. The dimension is more clearly distinguished in the private sector. In the public sector, many comparable tasks are identified as part of the communication manager role.

One conclusion based on the analysis is that the general picture of managerial roles among Swedish PR practitioners in Table 2 is to some extent a result of the different compositions of managerial roles in the private and the public sector. Even if there are similarities, there are substantial managerial role differences among PR practitioners in the two sectors. To put this somewhat differently, different demands and expectations are placed on PR managers in the public sector compared to those employed in private companies.

\section{Discussion and Conclusions}

One important conclusion is that the present study confirms previous findings showing that a simple dichotomy between managers and technicians cannot be used to understand the breadth of and nuances in the responsibilities of persons holding managerial level positions in the public relations context. In short, the reality of modern organizational life and functional responsibility is simply far too complex.

As mentioned earlier, the work of Moss, Newman and DeSanto (2005) was intended to broaden the perspective on core elements of management in public relations. When using the same survey methodology in a different national setting, in this case in Sweden, we can observe a number of important similarities in the 'picture' of the public relations managerial role activities revealed. In both countries, a five-factor solution was found, where the role as monitor/evaluator and key policy/strategy advisor is almost identical to that in the UK study.

There are also similarities in that PR managers in both countries sometimes have to perform elements of technical work; even this seems to entail fewer such tasks for PR managers in Sweden - especially in the private sector (Johansson \& Ottestig 2011). But there were differences, too, such as the identified stakeholder expert role found among Swedish managers, which had no clear parallel among British public relations managers. Comparisons with other studies show that the external and internal communication 
dimension is also crystallized in the Swiss study by Beurer-Züllig, Fieseler and Meckel (2009) as well in the Swedish study by Johansson and Ottestig (2011). The fact that the stakeholder and relational aspect emerges in the role battery is also in line with Gregory (2008) and her relational emphasis.

The analysis in which PR managers in the private and public sector were differentiated revealed a number of insights. Dimensions found on the general level were due to different role expectations in the private and public sector. The strategic function seems to be more predominant in private enterprise, which might have to do with the large number of public sector PR mangers working in politically steered organizations, where strategic issues are to some extent more political in its nature. Requirements of the PR function might therefore be more concerned with issues management and dealing with day-to-day demands than with strategic work at the top level of the organization. In the private sector, the policy adviser and strategist is also the monitor/evaluator.

The growing body of research outside the Anglo-American context on the PR function in organizations provides support for two important conclusions. First, the PR function seems to be more or less universal in organizations around the world. Previous research on PR and organizational roles may be heavily dependent on research from the US and the UK, nevertheless these findings seem to be supported by findings in other countries. The study of Beurer-Züllig, Fieseler and Meckel (2009) showed that different roles of PR work can be found in an all-European context, i.e. the PR practitioner profession shows the same divergence independent of the country studied. The second conclusion is that this dispersion of tasks performed in PR work is also found at the managerial level in different countries. This complexity of defined roles among general PR practitioners as well as among PR managers may indicate that the professionalization of PR is not as far reaching as has been argued. The division between managers and general PR practitioners is still blurred.

As a final conclusion this study indicates, in line with several other studies, not least Moss et al. (2005), that the 'role map' for PR/communication managers is complex and multifaceted. These managers perform a broad spectrum of duties and tasks, not only of a straightforward communication character but also of a service, support and advisory character. In sum, the PR/communication mangers play a composite role in their organizations.

One challenge also pointed out for future research is to further develop analyses of PR managerial roles in different types of organizations. Because results show that demands and expectations are different in the private and the public sector, we believe efforts should be made to better understand how different organizational conditions affect the responsibilities and tasks of the PR function and to explain how the PR function is organized and perceived by practitioners.

\section{References}

Berger, B. (2005) Power Over, Power With, and Power to Relations: Critical Reflections, The Dominant Coalition and Activism. Journal of Public Relations Research 17:1: 5-28.

Beurer-Züllig, B.; Fieseler, C.and Meckel, M. (2009) Typologies of European Communication Professionals. Corporate Communications 14:2: 158-175.

Broom, G. \& Sha, B.-L. (2013) Cutlip \& Center's Effective Public Relations. Boston: Pearson.

Broom, G. \& Dozier, D. (1986) Advancement for public relations role models. Public Relations Review 12:1:37-56. 
Broom, G. and Smith, G. (1979) Testing the Practitioner's Impact on Clients. Public Relations Review $5: 3: 47-59$.

Choi, J and Choi, Y. (2009) Behavioral dimensions of public relations leadership in organizations. Journal of Communication Management 13:4: 292-309.

Dozier, D. and Broom, G. (2006) The Centrality of Practitioner Roles to Public Relations Theory, in Botan, Carl \& Hazleton, Vincent (ed.) Public Relations Theory II. Mahwah, N.J.: Lawrence Erlbaum.

Dozier, D. et al. (1995) Manager's Guide to Excellence in Public Relations and Communication Management. Mahwah, N.J: Lawrence Erlbaum.

Dozier, D. (1984) Program Evaluation of Roles of Practitioners. Public Relations Review 10:2:13-21.

DeSanto, B. and Moss, D. (2004) Rediscovering what PR managers do: Rethinking the measurment of managerial behaviour in the public relations context. Journal of Communication Management 9:2:179-196.

Flodin, Bertil (2004) Sweden, in van Ruler, Betteke \& Vercic, Dejan (2004) Public Relations and Communication Management in Europe. Berlin: Mouton de Gruyter.

Galbraith, J. I., Bartholomew, David J., Moustaki, Irini and Steele, Fiona (2002) The analysis and interpretation of multivariate data for social scientists. Chapman \& Hall/CRC Statistics in the Social and Behavioral Sciences. CRC Press, London.

Gergory, Anne (2008) Competencies of senior communication practitioners in the UK: An initial study. Public Relations Review 34:3: 215-22.

Gilljam, M. and Hermansson, J. (2003) Demokratins mekanismer /Mechanisms of Democracy/. Malmö: Liber.

Grunig, L.; Grunig, J. and Dozier, D. (2002) Excellent Public Relations and Effective Organizations. Mahwah, N.J: Lawrence Erlbaum.

Grunig, James (1992) (ed.) Excellence in Public Relations and Communication Management.Hillsdale, N.J: Lawrence Erlbaum.

Ihlen, Ø. and van Ruler, B. (2009) Introduction: Applying Social Theory to Public Relations, in Ihlen; van Ruler and Fredriksson (eds.) Public Relations and Social Theory. London: Routledge.

Johansson, C. and Ottestig, A. (2010) Communication executives in a changing world: legitimacy beyond organisational borders. Journal of Communication Management 15:2:144-164.

Katz, D. and Kahn, R. (1978).The social psychology of organizations. New York: Wiley.

Kim, J.and Mueller, C.W. (1979). Introduction To Factor Analysis. What It Is and How to Do It. California, Sage Publications Inc.

Larsson, L. (2005) Upplysning och propaganda. Utvecklingen av svensk PR och information /Information and propaganda/. The development of Swedish PR/. Lund: Studentlitteratur.

Larsson, L. (2006) Public relations and democracy. The Swedish case, in L'Etang \& Pieczka (red.) Public Relations. Critical Debates and Contemporary Practice. Mahway, N. J.: LEA.

Leichty, G. and Springston, J. (1996) Elaborating Public Relations Roles. Journalism Quarterly 73:467-477.

Moss, D.; Newman, A. and DeSanto, B. (2005) What Do Communication Managers Do? Defining and Refining the Core Elements of Management in a Public Relations/ Corporate Communication Context. Journalism \& Mass Communication Quarterly 82:4:873-890.

Moss, D. and Green, R. (2001) Re-examining the manager's role in public relations:What management and public relations research tells us. Journal of Communication Management 6:2:118-132.

Moss, D.; Warnaby, G. and Newman, A. (2000) Public Relations Practitioner Role Enactment at the Senior Management Level Within UK Companies. Journal of Public Relations Research 12:4:277-307.

Reber, B. and Berger, B. (2006) Finding influence: examining the role of influence in public relations practice. Journal of Communication Management 10:3:225-249.

$\mathrm{SACP} / \mathrm{The}$ Swedish Association of Communication Professionals/Sveriges Kommunikatörer: Member survey 2010.

Steyn, B. (2009) The strategic role of public relations is strategic reflection: A South African research stream. American Behavioral Scientist, 53(4), 516-532.

Steyn, B. (2002) A meta-theoretical framework for the role of the corporate communication strategist. Communicare, 21(2), 42-63.

Tindall, N.T.J., and Holtzhausen, D.R. (2011) Toward a roles theory for strategic communication: The case of South Africa. International Journal of Strategic Communication, 5(2), 74-94.

Toth, E. et.al. (1998) Trends in public relations research, in Public Relations Research 5:3:153-175.

van Ruler, Betteke et al. (2001) Public relations in Europe: a kaleidoscopic picture.Journal of Communication Management 6:2:166-175.

van Ruler, Betteke \& Vercic, Dejan (2004) Public Relations and Communication Management in Europe. Berlin: Mouton de Gruyter.

Werder, K. P., \& Holtzhausen, D. (2009). An analysis of the influence of public relations department leadership style on public relations strategy use and effectiveness. Journal of Public Relations Research, 21(4), 404-427. 
Werder, K. P., \& Holtzhausen, D. (2011). Organizational structures and their relationship with communication management practices: A public relations perspective from the United States. International Journal of Strategic Communication, 5(2), 118-142.

Wright, D (1995) The role of corporate public relations executives in the future of employee communications. Public Relations Review 21:3:181-198.

Zerfass, Ansgar; Tench, Ralph; Verhoeven, Piet; Vercic, Dejan \& Moreno, Angeles (2010).

European Communication Monitor 2010. Berlin: EACD and EUPRERA.

Bengt Johansson, Ph.D., Professor, Department of Journalism, Media and Communication, University of Gothenburg, bengt.johansson@jmg.gu.se

Larsåke Larsson, Ph.D., Professor, School of Humanities, Education and Social Sciences, University of Örebro, larsake.larsson@oru.se 